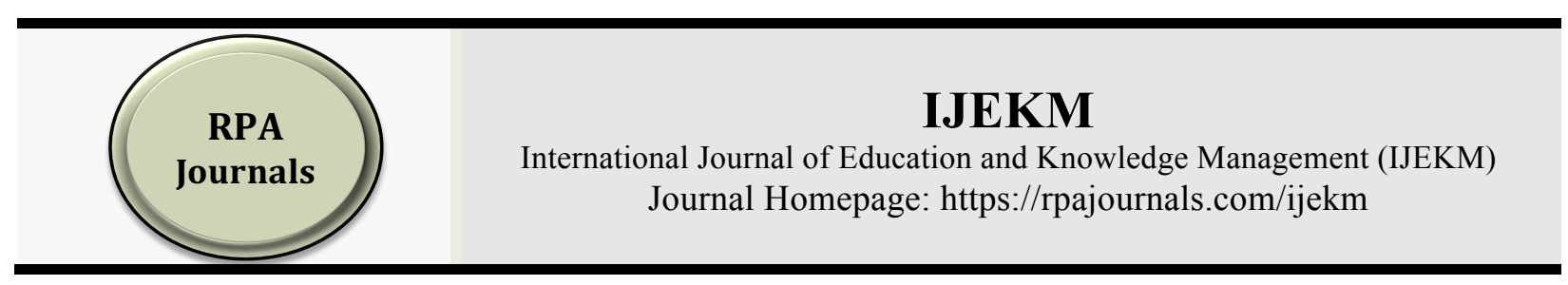

\title{
Investigating the Role of English Text in Character Building in the Context of the Private Institutes of Pakistan
}

\author{
Maria Sajid ${ }^{1^{*}}$ \\ Nadia Hanif ${ }^{2}$ \\ Bahria University, Lahore Campus, Pakistan ${ }^{1}$ \\ University of Management and Technology, Pakistan ${ }^{2}$
}

\begin{abstract}
The aim of the current study is to explore the extent to which designed curriculum helps students in developing their social and moral values. In order to achieve the mentioned purpose, a survey is carried out in a private institute of Lahore, Pakistan. English text from grade I is analyzed through a designed questionnaire. The questionnaire is based on Krawthol's affective domain and administered among teachers and administrators of all campuses with in the same institute to find the role of English text in character building of students. Purposive sampling technique is used to select a sample of 76 participants from the defined population. Data derived from questionnaires is statistically investigated, such as t-test, ANOVA, Cohan's d, eta and percentages. The survey result clearly shows the positive contribution of Grade I English text in character building of the students, presented in form of tables. Moreover, the research has imperative suggestions for teachers and curriculum developers for further research in the field of character building at elementary level.
\end{abstract}

Keywords: Character building (social and moral values), English Text, Grade I, Krawthol's Affective Domain

*Corresponding author: Maria Sajid; Email: maria.sajid17@gmail.com DOI: https://doi.org/10.37227/ARICON-2020-03-26

\section{Introduction}

"Human ethics and ideals, concepts and values, are a way of revealing the interior regions of man and the underlying dimensions of genuine life" (Ahmed, 2007, p.1). Education is a process that facilitates the individuals to adjust themselves in the society and fulfill their personal needs; and the nation to have a literate society and better quality of life. The most precious asset of any nation is its educational institutions. The quality of education directly effects the socio-economic development of a society. This is the reason why developed and developing nations have education as their main agenda and are tirelessly working to achieve it and social and moral values cannot be ignored in the process of educating children.

At every age, the individual is judged by how closely s/he conforms to the groups' standards, and he is labeled "moral" or "immoral", accordingly. Moral development is related to the rules that people have for their interaction with others. In the early stages, the child simply tries to avoid punishment as s/he cannot distinguish "right" from "wrong". Over time children's values are influenced by parents and educators as role models. 
Children's moral development is linked to their intellectual development. A significant and considerable role can be played by moral and social development in a child's life. It lays the foundation for social interactions and helps children adapt to the standards in their environments (Koenig et al., 2004). Like other areas of development this process is shown to develop along a continuum. As children's thinking evolves, they are slowly introduced to conflicts between personal needs and social norms (Hoffman, 1979).

\section{Background of the Study}

In history of Pakistan, children were often viewed simply as small versions of adults and little attention was paid to the many advances in cognitive abilities, language usage, and physical growth that occur during childhood and adolescence. Each child is unique, idiosyncratic and complex during the time of growth and development. With the advent of the $21^{\text {st }}$ century, individuals mainly children are facing a number of challenges in form of lack of social connectedness, shifting family dynamics, constant bombardment of real-time messages related to perfect bodies, economic and social status and growing crime and violence. The reality of these occurrences is all too present in a world that offers swift and ready access to highly advanced technology, information and communication (McGrath \& Noble, 2003). It brings a big challenge for teachers and parents that how to develop children into good and respectable human beings. It is the need of time to support and train children to turn into flexible beings, capable of managing transformations and challenging situations.

Developing personal and social skills in children at a young age can provide such support. The area is receiving significant amounts of attention from the fields of education and employment (Personal and Social Development Education Guidelines, 2008). Schools have a duty to play an important role in the spiritual, moral, cultural, mental and physical development of pupils. It is an imperative function of schools to develop a respect in the pupils for their own and others' beliefs, culture and identity.

\section{Statement of the Research Problem}

The content used in English language classes generally focuses on factual language skills and tends to ignore social and moral values (Diamond, Justice, Siegler \& Snyder, 2013). It does not seem to be supportive in developing empathy and building character of the learners (Roy, 2013). The current research tends to explore these causes and identify the problems of these deficiencies in the text taught for English language.

\section{Objective and Significance of the Research}

The main objective of this research is to find out the opinions of the teachers and administrators regarding development of empathy, respectful behaviour, caring attitude, honesty and perseverance in the students through English text. Character building in this study is operationalised as development of empathy, respect, caring attitude, honesty and perseverance according to Krawthol's affective domain.

The finding of this study would be significant for all stake holders. The results of this study may provide guidance for administration of Schools to understand character education as an integral part of academic life for a student. The results would also make teachers conscious about the importance of hidden curriculum when they import language in students regarding their social and moral development. The syllabus designers would get awareness about the groomed students and consider it as an essential part of their learning. 
The results of the current study might be helpful in the life of students to develop into distinguished citizen and a model for other members of society. The outcome of this current research could be supportive for parents to communicate basic rules in the life of students.

\section{Literature Review}

Character and morality are a view of being wicked and decent towards any situation that based on certain norms and principles those are already developed (Kaur, 2015). According to Kaur (2015) respect, responsibility, integrity and honesty are the main foundations of character building. Character is seen from one's behaviors through words and deeds. Roseth (2016) defines character as "two essential and connected parts: performance character and moral character". When one uses the term character, it consists of two essential interrelated parts which are performance character and moral character.

\section{Character Education}

In Pakistan, the need for personal and social development in education sector was first identified by the founder of the country. According to Quaid-e-Azam Mohammed Ali Jinnah, (1947) "Education does not merely mean academic education. You have to build the character of our future generations which means highest sense of honor, integrity, selfless service to the nation and a sense of responsibility."

Character building is an important discipline with the deliberate attempt to augment students' ethical and moral behavior (Katilmis, Eksi, \& Öztürk, 2011). Pike (2010) explained that the functions of schools is not only the enhancement in academics but to guide and instruct students towards a prescribed behavior. According to Foster (2011), through character education some kind of ways can be prescribed where students can be nurtured and see the things in different perspectives.

In a society where school violence, tobacco and alcohol use among underage students, and bullying were on the rise and unacceptable and inappropriate student behavior was increasing, there needed to be a nationwide, conscious effort to promote prosocial, positive character development among students (Brannon, 2008)

\section{Role of Teachers for Character Building}

The teachers hold an authoritative role in the eyes of the students, it is inevitable for teachers to serve as moral agents or moral exemplars of students' moral character development (Campbell, 2008; Frenstermacher, 2001; Katz, Noddings \& Strike, 1999). Furthermore, given the long hours that students spend with teachers within the school community, there is an expectation on teachers to play a critical role in the moral character formation of students besides helping them to learn academic content (Watson, 2008).

\section{Children Literature and Text used for Character Building}

According to Gunning (2012) literature books have much flexibility in their writing style to enrich the content with originality of style and creativity. Through literature it is convenient to pass positive character traits. Although Roy (2013) restraint by adding that it happens by keeping the character building in main focus while designing. Tornroos (2004) used the term "potentially implemented curriculum" (p. 2) to describe the role of the textbook and other curriculum materials in a classroom in the light of written curriculum. This role of textbooks constitutes a transitional stage between the intended curriculum and 
the implemented curriculum. Increased attention is being paid to quality of textbooks across the globe.

According to Moir (2016) pressure of academics standard has pushed away the character education from the class room although English text including other content used in classroom has a strength to establish positive attitude within the students that can keep them away from negative thoughts and avoidable activities. Mahmood (2011) suggests that the books prescribed in the curriculum should be evaluated against these criteria that should include every aspect of a child's development. "The primary purpose of school is to promote academic skills, but school is a social setting in which the social and academic domains are inextricably connected" (Miles \& Stipek, 2006, p. 103); therefore, schools must fill the void and assume the necessary responsibility of moral education (Zdenek \& Schochor, 2007; Lickona, 1991). In response, many schools have turned to character education in an effort to teach students positive values and right conduct. President Obama gave his Back to School Speech in Arlington,Virginia, he declared responsibility and respect as important factor not only for the education even for the students' life. He also discussed about the decision power of students which can support them and give them strength even when they do not have money and focused to set their goal for their education and life. The President's speech was sprinkled with character words from beginning to end. Students needed to learn how to be good citizens in a safe environment that was conducive to learning (Whitehouse.gov, 2009).

\section{Rationale of the Study}

Globally numerous researches and work has been done in the field of social and moral development incorporated in the school curriculum however not much have been done in Pakistan. There are few studies especially with the focus on empathy, respect, caring attitude, honesty and perseverance in the context of private school systems in Pakistan. The present study aims to fill this gap and provide an independent view of discovering the measures taken by educational institutions, particularly teachers, to integrate personal and social development themes in textbooks in the Pakistani context. Thus, the study would not only be useful in filling the literature gap, it would also provide educators with useful means to incorporate academic learning and personal and social development in children.

Beaconhouse School System has its own curriculum in a form of complete guideline for teachers to be focused for the benefits of the students. For the subject of English complete guide lines are given at each level for different skills. For this purpose different readers are used as a text in the classrooms. In few readers there are some hidden moral lessons shown by different characters. However, those traits of different characters are not highlighted or presented as model traits for students. Few characters traits were described only to enhance the skill of character description. Some specific activities are designed which can develop empathy, respect, honesty, caring and perseverance among students.

\section{Research Methodology}

In terms of the research approach, quantitative research method was used as it is an apropriate and also an authentic way for asking individuals to self-report about particular behaviors, beliefs, attitudes, opinions, characteristics, expectations, self-classification, and knowledge (Hagan, 2006). In order to gather pertinent data, questionnaire was used for investigating the case study. Essentially, the researcher was concerned in obtaining data 
from English teachers in schools who interact with students on a daily basis within the classroom setting.

\section{Population and Sampling}

As the research used a survey design approach, only one school system, Beaconhouse School System was selected. Purposive sampling technique was used to select a sample of 76 participants from the defined population. The sampling units for purposive sampling are selected based on the researcher's judgment of what units will facilitate an investigation (Adler \& Clark, 2008). The samples included English teachers and administrators of class I as they are the ones teaching the English text. Class I was selected because age between five to seven years is the critical age for character building.

\section{Construction of Research Instrument}

In order to gather standardised, factual data a survey was conducted, through running a questionnaire among the English teachers and administrators of grade I. The questionnaire included a variety of close-ended items to gain quantitative responses (see Appendix A) for teachers and for administrators. Those questions were based on to Krawthol's affective domain (Krathwhol, Bloom \& Masia, 1964). The rating scale included a Likert type scale in which respondents were asked to rate their responses on a scale from strongly disagree to strongly agree. In terms of the contents of the questionnaire, it began with collating general information about the respondents such as gender, age, teaching experience and position held in school.

\section{Reliability and Validity of the Tool}

To ensure the reliability of the tool, a pilot study was conducted in two branches of the required sample. Study was accomplished in time and respondents were able to comprehend the required questions. For internal reliability, a statistical check known as Cronbach's alpha was applied after administration. The alpha value of teachers' questionnaire was .953 and the alpha value of administrators, questionnaire was .791. To obtain the content validity, the items from the questionnaire were taken from the literature review (see Lichona 2004; Bohling 2005; Elkind and Sweet 2007)

\section{Data Analysis}

The filled questionnaire were coded and entered in computer for analysis with SPSS (version 15.0). For summarizing data, mean $(M)$ and standard deviation $(S D)$ were calculated. Different tests such as t-test, ANOVA, Cronbach's alpha, Cohen's d and eta test were applied on the data to analyse the opinion's from each aspect.

\section{Research Ethics}

Research ethics were kept under consideration before the research was conducted. Permission was taken from the school administration before carrying out the research and they were presented the permission letter obtained from the researcher's university to verify the research purpose. All researchers are responsible for ensuring that participants are well informed about the purpose of the research they are being asked to participate in (Fritz, 2008). Consent was taken from the teachers and their administration. 
The most considerable apprehension related to respondent protection is the defense of their privacy. All the participants in the study were assured privacy and confidentiality of the data collected as well as the purpose of the research (Walliman, 2010).

\section{Results}

In terms of the research approach, quantitative research method was used and different statistical tests have been applied such as t-test, ANOVA, Cohan's d, eta and percentages to show the final collected data results to explore the extent to which English text taught to the students of grade I promote and develop different factors related to character building. Results have been presented in form of tables for further clarification.

\section{Questionnaire Analysis}

A survey was conducted among 51 grade I's English teachers including 25 administrators to determine their perceptions of the actual implementation for the character building of students. The results derived from the survey have been tabulated and interpreted using Microsoft Excel.

Tables summarize means and standard deviations of the results. After that interprtations are given for the presented results

Table 1: Responses of Administrators about the Development of Empathy

\begin{tabular}{lllllllll}
\hline A. & Statement & $S D$ & $D$ & $N$ & $A$ & $S A$ & $M$ & $S D$ \\
\hline 1. & $\begin{array}{l}\text { Accept empathetic behaviour while } \\
\text { reading text }\end{array}$ & 2.9 & 17.6 & 8.8 & 61.8 & 8.8 & 3.56 & 0.99 \\
2. & $\begin{array}{l}\text { Discuss empathy in class while dealing } \\
\text { with other class mates }\end{array}$ & 2.9 & 11.8 & 17.6 & 58.8 & 8.8 & 3.59 & 0.92 \\
3. & $\begin{array}{l}\text { Differentiate empathetic behaviour } \\
\text { while talking about matters }\end{array}$ & 5.9 & 2.9 & 20.6 & 61.8 & 8.8 & 3.65 & 0.92 \\
4. $\begin{array}{l}\text { Adapt empathetic behaviour while } \\
\text { dealing with issues/ problems }\end{array}$ & 5.9 & 5.9 & 20.6 & 38.2 & 29.4 & 3.79 & 1.12 \\
5. & $\begin{array}{l}\text { Perform empathetic behaviour by } \\
\text { helping others }\end{array}$ & 5.9 & 0 & 17.6 & 55.9 & 20.6 & 3.85 & 0.96 \\
\hline
\end{tabular}

Table 1 shows that (70.6\%) administrators agreed that students accept empathetic behaviour through English text. More than half $(67.6 \%)$ of administrators agreed that students discuss empathy in class while dealing with other class mates. The mean score $(M=3.85, S D=0.96)$ reveal the fact that students perform empathetic behaviour.

Table 2: Responses of Teachers about the Development of Respect

\begin{tabular}{|c|c|c|c|c|c|c|c|c|}
\hline$B$ & Statement & $S D$ & $D$ & $N$ & $A$ & $S A$ & $M$ & $S D$ \\
\hline 1. & $\begin{array}{l}\text { Observe respectful behaviour during } \\
\text { the class discussion }\end{array}$ & 1.4 & 5.6 & 19.7 & 50.7 & 22.5 & 3.87 & 0.88 \\
\hline 2. & $\begin{array}{l}\text { Behave respectfully while talking to } \\
\text { junior staff members }\end{array}$ & 0 & 16.4 & 17.8 & 43.8 & 21.9 & 3.71 & 0.99 \\
\hline 3. & Prefer respect on all other matters & 0 & 8.2 & 30.1 & 39.7 & 21.9 & 3.75 & 0.89 \\
\hline 4. & Organize respectful behaviour while & 0 & 19.2 & 31.5 & 32.9 & 16.4 & 3.47 & 0.99 \\
\hline
\end{tabular}




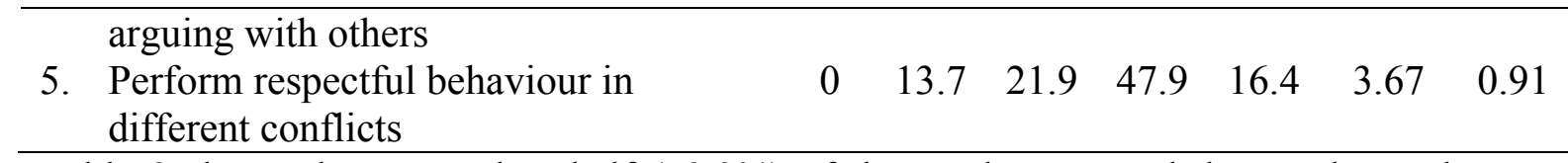

Table 2 shows that more than half $(73.2 \%)$ of the teachers agreed that students observe respectful behaviour during the class discussion. The mean score $(M=3.9, S D=0.88)$ present the observation of respectful behaviour.

Table 3: Responses of Administrators about the Development of Caring Attitude

\begin{tabular}{|c|c|c|c|c|c|c|c|c|}
\hline$C$ & Statement & $S D$ & $D$ & $N$ & $A$ & $S A$ & $M$ & $S D$ \\
\hline 1. & Realize th & 2.9 & 2. & 17.6 & 67.6 & 8. & 3.76 & 0.78 \\
\hline 2. & $\begin{array}{l}\text { the caring attitude during class } \\
\text { es }\end{array}$ & 2.9 & 118 & 8.8 & 4.7 & 11.8 & 3.71 & 0.94 \\
\hline 3. & $\begin{array}{l}\text { Value the caring attitude while playing } \\
\text { in ground }\end{array}$ & 8.8 & 5.9 & 8.8 & 70.6 & 5.9 & 3.59 & 1.02 \\
\hline 4. & $\begin{array}{l}\text { Analyse the outcomes of caring } \\
\text { attitude }\end{array}$ & 6.1 & 9.1 & 21.2 & 51.5 & 12.1 & 3.55 & 1.03 \\
\hline 5. & $\begin{array}{l}\text { Construct good relations through caring } \\
\text { attitude }\end{array}$ & 6.1 & 6.1 & 15.2 & 51.5 & 21.2 & 3.76 & 1.06 \\
\hline
\end{tabular}

Table 3 shows that $(76.5 \%)$ administrators agreed that students realize the effects of caring attitudes. The mean score $(M=3.8, S D=0.78),(M=3.8, S D=1.06)$ depict the relations through caring attitude and effect of caring attitude.

Table 4: Responses of Administrators about the Development of Honesty

\begin{tabular}{|c|c|c|c|c|c|c|c|c|}
\hline$D$ & Statement & $S D$ & $D$ & $N$ & $A$ & $S A$ & $M$ & $S D$ \\
\hline 1. & $\begin{array}{l}\text { Quote different events related to } \\
\text { honesty during the discussion of moral } \\
\text { lesson }\end{array}$ & 8.8 & 2.9 & 20.6 & 58.8 & 8.8 & 3.56 & 1.02 \\
\hline 2. & $\begin{array}{l}\text { Locate the factor of honesty while } \\
\text { describing any character }\end{array}$ & 2.9 & 2.9 & 29.4 & 52.9 & 11.8 & 3.68 & 0.84 \\
\hline 3. & $\begin{array}{l}\text { Solve matters with honesty while } \\
\text { dealing with other class mates }\end{array}$ & 2.9 & 5.9 & 32.4 & 50 & 8.8 & 3.56 & 0.86 \\
\hline 4. & $\begin{array}{l}\text { Outline the boundaries of honesty } \\
\text { while playing a game }\end{array}$ & 2.9 & 5.9 & 32.4 & 50 & 8.8 & 3.56 & 0.86 \\
\hline 5. & $\begin{array}{l}\text { Represent honesty as a best policy } \\
\text { while writing narrative }\end{array}$ & 2.9 & 11.8 & 23.5 & 44.1 & 17.6 & 3.62 & 1.02 \\
\hline
\end{tabular}

Table 4 shows that mostly administrators (67.6\%) agreed that students quote different events related to honesty during the discussion of moral lesson. The mean score $(M=3.68$, $S D=0.84) 3.68$ disclose the locating factor of students for honesty. 
Table 5: Responses of Teachers about the Development of Perseverance

\begin{tabular}{|c|c|c|c|c|c|c|c|c|}
\hline & Statement & $S D$ & $\bar{D}$ & $N$ & $A$ & $S A$ & $M$ & $S D$ \\
\hline 1. & $\begin{array}{l}\text { Receive perseverance while reading } \\
\text { text }\end{array}$ & 0 & 24.7 & 16.4 & 49.3 & 9.6 & 3.44 & 0.97 \\
\hline 2. & $\begin{array}{l}\text { Show perseverance while defending } \\
\text { their view point during discussions }\end{array}$ & 0 & 20.5 & 20.5 & 49.3 & 9.6 & 3.48 & 0.93 \\
\hline 3. & $\begin{array}{l}\text { Balance their perseverance while } \\
\text { showing flexibility to classmates }\end{array}$ & 2.7 & 15.1 & 24.7 & 37 & 20.5 & 3.58 & 1.07 \\
\hline 4. & $\begin{array}{l}\text { Improve their perseverance while } \\
\text { facing different academic and social } \\
\text { problem }\end{array}$ & 2.7 & 9.6 & 28.8 & 38.4 & 20.5 & 3.64 & 1.01 \\
\hline 5. & $\begin{array}{l}\text { Authenticate perseverance while } \\
\text { presenting themselves in front of } \\
\text { seniors }\end{array}$ & 1.4 & 12.3 & 26 & 43.8 & 16.4 & 3.62 & 0.95 \\
\hline
\end{tabular}

Table 5 represents that more than half ( $58.9 \%)$ teachers agreed that students improve their perseverance while facing different academic and social problems. (60.2\%) teachers agreed that students authenticate perseverance while presenting themselves in front of seniors.The mean score $(M=3.6, S D=1.07),(M=3.6, S D=1.01),(M=3.6, S D=0.95)$ explore that the students balance, authenticate and improve their perseverance.

Table 6 : Comparison of Teachers and Administrators

\begin{tabular}{lcccccccccc}
\hline Character & \multicolumn{1}{c}{ Administrators } & \multicolumn{2}{c}{ Teachers } & & t-value & $p$-value & $d^{*}$ \\
building factors & $N$ & $M$ & $S D$ & $n$ & $M$ & $S D$ & & & \\
\hline Empathy & 34 & 18.44 & 4.02 & 73 & 17.82 & 3.38 & 0.83 & 0.408 & 0.067 \\
Respect & 34 & 18.18 & 3.46 & 73 & 18.37 & 3.73 & -0.26 & 0.799 & 0.007 \\
Caring Attitude & 34 & 18.15 & 4.29 & 73 & 18.84 & 3.41 & -0.89 & 0.373 & 0.077 \\
Honesty & 34 & 17.97 & 3.48 & 73 & 18.64 & 3.83 & -0.87 & 0.386 & 0.074 \\
Perseverance & 34 & 16.32 & 4.30 & 73 & 17.75 & 4.13 & -1.65 & 0.103 & 0.266 \\
\hline *d=Cohen's & & & & & & & & &
\end{tabular}

Table 6: The result of independent samples t-test $(\mathrm{t}=0.83, \mathrm{p}=0.408)$ shows that there is statistically significant difference between teachers and administrators' opinion about the development of empathy among students. The result of independent sample $t$-test $(t=-0.26$, $\mathrm{p}=0.799$ ) shows that there is no statistical significant difference between administrators and teachers' opinion about the development of respect among student, $(\mathrm{t}=-0.89, \mathrm{p}=0.373)$ shows that there is statistical significant difference between administrators and teachers' opinion about the development of caring attitude among students 
Table 7: Comparison of Experience

\begin{tabular}{|c|c|c|c|c|c|c|c|c|c|}
\hline \multirow{3}{*}{$\begin{array}{l}\text { Character building } \\
\text { factors }\end{array}$} & \multicolumn{6}{|c|}{ Experience (years) } & \multirow{3}{*}{$\begin{array}{l}F- \\
\text { value }\end{array}$} & \multirow{3}{*}{$\begin{array}{l}p- \\
\text { value }\end{array}$} & \multirow{3}{*}{$\eta^{2}$} \\
\hline & \multicolumn{2}{|l|}{$<5$} & \multicolumn{2}{|c|}{$5-15$} & \multicolumn{2}{|l|}{$>15$} & & & \\
\hline & Mean & $S D$ & Mean & $S D$ & Mean & $S D$ & & & \\
\hline Empathy & 17.72 & 3.65 & 17.94 & 2.85 & 18.50 & 4.59 & 0.37 & 0.69 & .23 \\
\hline Respect & 19.22 & 3.11 & 17.77 & 3.34 & 18.18 & 4.48 & 1.57 & 0.21 & .26 \\
\hline Caring Attitude & 19.19 & 3.29 & 18.47 & 3.36 & 18.21 & 4.65 & 0.58 & 0.56 & .21 \\
\hline Honesty & 19.19 & 3.85 & 18.43 & 2.78 & 17.57 & 4.76 & 1.42 & 0.25 & .09 \\
\hline Perseverance & 18.41 & 3.93 & 16.94 & 3.47 & 16.64 & 5.43 & 1.63 & 0.20 & .15 \\
\hline
\end{tabular}

$\eta^{2}=$ effect size

Table 7 shows that there is no statistically significant difference between three categories about the development of empathy among students. The result ANOVA $(F=1.57, p=0.21)$ shows that there is no statistically significant difference between three categories about the development of respect among students.

Table 8: Comparison of Designation

\begin{tabular}{lccccccccr}
\hline $\begin{array}{l}\text { Character } \\
\text { buildingfactors }\end{array}$ & \multicolumn{1}{l}{ Coordinators } & Teachers & & Headmistress & $\begin{array}{l}F- \\
\text { value }\end{array}$ & $\begin{array}{l}p \text { - } \\
\text { value }\end{array}$ & $\eta^{2}$ \\
& $M$ & $S D$ & $M$ & $S D$ & $M$ & $S D$ & & & \\
\hline Empathy & 18.00 & 4.42 & 17.92 & 3.36 & 18.77 & 4.36 & 0.30 & 0.740 & .006 \\
Respect & 17.54 & 4.72 & 18.43 & 3.64 & 19.23 & 2.35 & 0.70 & 0.501 & .014 \\
Caring Attitude & 17.31 & 5.20 & 18.92 & 3.27 & 18.08 & 4.11 & 1.22 & 0.299 & .024 \\
Honesty & 17.31 & 4.19 & 18.76 & 3.70 & 18.08 & 3.48 & 0.93 & 0.400 & .02 \\
Perseverance & 15.54 & 4.24 & 17.83 & 4.07 & 15.69 & 5.07 & 2.65 & 0.076 & .05 \\
\hline$\eta^{2}=$ effect size & & & & & & & & &
\end{tabular}

Table 8 shows the result ANOVA $(\mathrm{F}=0.30, \mathrm{p}=0.740)$ shows that there is no statistically significant difference between three categories about the development of empathy among students. The result of ANOVA $(\mathrm{F}=0.70, \mathrm{p}=0.501)$ shows that there is no statistically significant difference between three categories about the development of respect among students.

Table 9: Comparison of qualification

\begin{tabular}{lccccccccc}
\hline $\begin{array}{l}\text { Character } \\
\text { buildingfactors }\end{array}$ & \multicolumn{4}{c}{ BA/B.Sc } & \multicolumn{7}{c}{ MA/M.SC } & t-value & p-value & $d^{*}$ \\
& $N$ & $M$ & $S D$ & $N$ & $M$ & $S D$ & & & \\
\hline Empathy & 29 & 17.31 & 4.32 & 72 & 18.33 & 3.28 & 1.29 & 0.200 & 0.167 \\
Respect & 29 & 18.21 & 3.97 & 72 & 18.50 & 3.54 & 0.36 & 0.717 & 0.013 \\
Caring Attitude & 29 & 18.34 & 4.24 & 72 & 18.71 & 3.45 & 0.45 & 0.655 & 0.020 \\
Honesty & 29 & 18.24 & 4.03 & 72 & 18.58 & 3.63 & 0.41 & 0.679 & 0.017 \\
Perseverance & 29 & 17.07 & 4.20 & 72 & 17.33 & 4.36 & 0.28 & 0.781 & 0.008 \\
\hline
\end{tabular}

$* \mathrm{~d}=$ Cohen's d

Table 9 shows the result of t-test used for the comparison of qualification about the factors of character building. The result of independent samples $t$-test $(t=1.29, p=0.200)$ shows that there is no statistically significant difference between both category about the development of empathy among students. The result of independent samples $t$-test $(t=0.36$, 
$\mathrm{p}=0.717$ ) shows that there is no statistically significant difference between both category about the development of respect among students.

\section{Discussions}

The overall results of the study indicate that various factors related to character building are implemented in classrooms to some extent; however it lacked consistency due to time constraints and pressures to achieve the curriculum objectives. The understanding for the asked factors were very clear to teachers which supports Dewey,1932, indicating that society and generations know what they have to teach. Literature also reveals that English text has abilitiy in providing a supportive and caring enviornment prevents children from indulging in unhealthy and difficult behaviours and endorses positive growth (Jweid \& Rizzo,2003). A significant aspect of the study was the identification of the part played by English text and relevant activities for the character building. Strong morals and values can assist students with everyday decision-making and problem-solving skills.

Textbook development and evaluation is a critical issue and has always been topic of dispute. There are a variety of causes for this, but generally non-availability of an overt criterion for textbook evaluation is one of the major problems (Mahmood, 2011).

The background information in tables 1 and 2 show that most of administrators and teachers agree that students learn and adopt such behaviour which provokes them to show and perform empathy. It means English text gives some models or hidden empathetic lessons which motivate students to adapt empathy. The result of this study contradicts Freud (1958) and Piaget (1965) who considered children egocentric and not able to perform empathy.

According to the administration and teachers, students observe respectful behaviour and similarly most of them agree that students reflect the same behaviour while dealing with junior staff members. The text used for teaching English is administrating them that how to behave with respect even arguing on different conflicts.

Authors adapted different approaches in the textbooks which need different pedagogical approaches to deliver the textbook in the classroom. This issue could potentially explain the effects of disorientation and lack of ability to make meaning out of the relevant textbooks experienced by many students (Alexander \& Kulikowich, 1994; Keys, 1999; Patterson, 2001; Yore, Craig, \& Maguire, 1998). A largest part of administration and teachers have the same opinion about the caring attitude of grade I students. They agree that students realize the effect of caring attitude and well aware about the positive effect of care. Students learn caring attitude from the text used in English class and present it as they read. Caring for others can be learnt by observing different models, which students can do in their classroom and school environment (Bulach, 1998; Deiro, 1996; Sham, 1999).

The administrations' and teachers' views confirm the development of honesty among students. They agree that students quote honesty as moral while writing stories and other events because they use different narratives and events with same moral lesson. Students prefer honesty on all other matters as they find out from the discussion and from text used in English class.

The research findings reveal that classroom environment is the foremost factor infacilitating for the development of different factors related to character building and development of honesty in students is one of them. Teachers are the cornerstone in creating a learning and supportive climate, it is crucial for them to develop healthy and constructive 
student-teacher relationships to influence favourable outcomes (Reddy, Rhodes, \& Mulhall, 2003).The result of table 4 reveal consensus of teachers on the development and implementation of honesty in the classroom environment. Teachers believe that students relate their narrative with honesty and students of grade 1 build up their boundaries on the foundation of honesty.

Administration and teachers of grade I agreed that students determined on their view point while convincing other members. According to their responses students are well aware that how to balance perseverance while handling matters in classroom. Teachers realized that students of grade 1 learn that how to show stability and present analysis with confidence and logics.

Hamdona (2007) also indicates that development of character building in content would lead to personal growth and social skills which contributes to the constructive social functioning of a child's behaviour in the classroom, school, family and society. Thus, this study offers useful insights into the manner in which educational institutions in Pakistani context incorporate the character building in classroom and the extent to which existing literature supports or contradicts this phenomenon.

The background information in table from 11 to 14 indicates there is no significance difference with the reference of experience, designation and qualification. The result shows the teachers and administrators with different experience, designation and qualification give importance to character building of students. According to their view point empathy, respect, caring attitude, honesty and perseverance among the students of grade 1 through English text is a vital factor. English teaching can provide a foundation on which the building of strong and good character can be stand. It can be conducted through four basic strands of English teaching, for instance listening, reading, speaking and writing. Teachers realized the morals values embedded in the materials, used for teaching English.

\section{Implications}

the literature gap of character building in early education in the Pakistani context, but also provides teachers and educational institutions with useful insights into ways in which they can incorporate character education through textbooks. It verifies the assumption that the character building through English text could facilitate the achievement of the desired outcomes. The corroboration between the research findings of this dissertation and those from the existing literature further underline the importance of exploring the extent to which development of character building incorporated in text for young learners. In terms of practical implications, school personnel could utilise this study to formulate teaching methodologies and activities to successfully impart character development in children. This research offers an in-depth understanding of the importance of textbook evaluation before prescribing it in the curriculum as well as its importance in determining learners' character building. It is a guidance tool for parents and teachers alike on how to facilitate growth of personal and social skills in children. Thus, incorporation of high-quality textbooks in the curriculum and consistent implementation, as reported by this research, could help teachers and educational institutions in successfully infusing the character building in students.

\section{Research Limitation and Direction for Future Studies}

The researcher encountered certain inevitable difficulties and challenges during the research process. It has certain limitation particularly for sample and approach of research. The search for schools implementing social and moral development in their curriculum led 
to a single institution that limited the scope of the study. Due to the lack of diversity within the sample, this study was not able to examine differences with the text used in other private or public schools for English. This study was interested in investigating only administration and teachers' responses for evaluating English text. Because of the shortage of time this study was confined only to Beaconhouse School System Lahore.

Further research in this area could be conducted by studying empirically the impact of incorporating the development of character building in the curriculum. A longitudinal research could also be conducted to determine the effects of character building on students' academic achievements and progress in real life. Moreover, a comparison of public and private schools could be conducted to study the implementation of character development.

\section{Conclusion}

Character building in young learners tends to determine the manner in which they interact with their surroundings as well as the ways in which they assert themselves in relationships with their significant others. In order to gain further insights, this research paper aimed at determining the extent to which development of empathy, respect, caring attitude, honesty and perseverance are incorporated in text for young learners. For this purpose, perceptions of teachers and administrators were examined and evaluated to find out the actual implementation of the development of character building in the students of grade 1 through textbooks.

The research results highlighted:

The administrators and teachers think that students accept empathetic behaviour and show empathy for others as they are learning empathy from English text. They tend to believe that the students of grade 1 can differentiate empathetic behaviour when they deal with other people. They believe that text books and activities in nurturing children into effective problem solvers and creative learners as well as respectable members of the society. On the basis of later analysis in the previous chapters, this study concludes that teachers and administrators believe on the role played by English text in the development of respect in children. According to them English text is an essential tool in learning and performing respectful behaviour. Moreover, teachers and administrators tend to agree on the development of caring attitude among the students of grade 1 through English text. Their responses show that students of grade 1 can realize the positive effect of caring attitude and make their relations by taking care of others. Teachers and administrators think that students of grade 1 take care of each other in every situation.

Research findings tell that teachers and administrators of grade 1 seem to believe on the development of honesty in the students. They learn honesty as a best policy through their English text. The factor of honesty can be found while students of grade 1 write a narrative or describe a character. The results of the research show the optimistic view of teachers and administrators for the development of perseverance among the students of grade 1 through English text. They tend to agree that students of grade 1 receive perseverance through English text and learn how to balance it while handling different matters in class room. Teachers and administrators believe that students of grade 1 improve perseverance through English text and learn that how to behave and show perseverance while facing social matters and deal with seniors.

This finding was reiterated through textbooks evaluations which revealed that majority of the books used in English class incorporate character building through different

International Journal of Education and Knowledge Management (IJEKM) 
stories and defining the character traits of special characters of stories Correspondingly, reliable and valid criterion to measure the quality of the textbooks should be employed to warrant the inclusion of a variety of skills and dimensions of the development of character building in classrooms.

\section{References}

Adler, E.S. \& Roger Clark. (2008), An invitation to social research: How it's done. (3 ${ }^{\text {rd }}$ ed).Belmont, CA: Thomson.

Ahmed, A. (2007). "Ethical virtue: In the Qur'anic perspective". Tanzeem -e-Islami, Retrieved 5 May, 2014 from http://www.tanzeem.org/resources /articles /print article. asp ?id=152/

Alexander, P. A., \& Kulikowich, J. M. (1994). A secondary analysis: Learning from physics text. Journal of Research in Science Teaching, 31, 895-911. https://doi.org/10.1002/tea.3660310906

Aron, A., \& Aron, E. N. (1997). Statistics for the behavioral and Social Sciences: A brief course. Upper Saddle River, NJ: Prentice Hall.

Brannon, D. (2008). Character education: It's a joint responsibility. Kappa Delta Pi, 44(2), 62-65.

Bulach, C. R., Brown, C., \& Potter, L. (1998). Behaviors that create a caring learning community. Journal for a Just and Caring Education, 4(4), 441 -453.

Campbell, E. (2008). Teaching Ethically As a Moral Condition of Professionalism. In L.P., Nucci, \& D., Narvaez (Eds.), Handbook of Moral and Character Education. London: Routledge.

Diamond, K. E., Justice, L. M., Siegler, R. S., \& Snyder, P. A. (2013). Synthesis of IES research on early intervention and early childhood education (NCSER 2013-3001). Washington, DC: National Center for Special Education Research, Institute of Education Sciences, U.S. Department of Education. Retrieved from http://ies.ed.gov/ncser/pubs/20133001/ pdf/20133001.pdf

Deiro, J. A. (1996). Teaching with heart: Making healthy connections with students. Thousand Oaks, CA: Corwin Press.

Dewey, J. (1932). Democracy and Education. Westport: Greenwood.

Elkind, D.H., Sweet, F. (2007). How to Do Character Education:You are a character educator. Journal of Education, 20(4), 23-26.

Freud, S. 1958. Civilization and its discontents. New York: Doubleday Anchor Books.

Fritz, K. (2008). Ethical issues in qualitative research. BloomBerg: John Hopkins School of Public Health.

Gunning, T. (2012). Building literacy in secondary content area classrooms. Boston: Pearson.

Hamdouna, Y. O. (2007). Life Skills Latent in the Content of English for Palestine - Grade Six Textbook. Gaza: The Islamic University of Gaza. Retrieved from http://library.iugaza.edu.ps/Thesis/74439.pdf

Hagan, F. E. (2006). Research methods in criminal justice and criminology (7th ed.). Boston: Pearson Education, Inc.

Hoffman, M. L. (1979). Development of moral thought, feeling, and behavior. American Psychologist, 34(10), 958-966.

Jinnah, A. (1947) Jinnah Speeches Retrieved on 20th June 2018 from http://www.pakobserver.net/JassimTaqui\%20Diplomatic\%20Focus1.asp 
Katz, M.S., Noddings, N., \& Strike, K.A. (1999). Justice and caring: The search for common ground in education. Teacher College Press: New York

Kaur, S. (2015) Moral Values in Education. Guru Gobind Singh Khalsa College for Women, Jhar Sahib. IOSR Journal of Humanities and Social Science, 20(3), 2126.ISSN: 2279-0837, p-ISSN: 2279-0845.

Katilmis, A., Eksi, H., \& Öztürk, C. (2011). Efficiency of social studies integrated character education program. Educational Sciences: Theory \& Practice, 11(2), 854859.

Keys, C. W. (1999). Language as an indicator of meaning generation: An analysis of middle school students' written discourse about scientific investigations. Journal of Research in Science Teaching, 36, 1044-1061.

Koenig, A. L., Cicchetti, D., \& Rogosch, F. A. (2004). Moral development: The association between maltreatment and young children's pro social behaviors and moral transgression. Social Development, 13(1), 97106. https://doi.org/10.1111/j.1467-9507.2004.00258.x

Krathwohl, D. R., Bloom, B. S., \& Masia, B. B. (1964). Taxonomy of educational objectives: the classification of educational goals (Affective domain, Vol. Handbook II). New York: David McKay.

Lickona, T. (1991). Educating for character: How our schools can teach respect and responsibility. New York: Bantam Books.

Mahmood, K. (2011). Conformity to quality characteristics of textbooks: The illusion of textbook evaluation in Pakustan. Journal of Research and Reflections in Education , 5(2), 170-190.

McGrath, H., \& Noble, T. (2003). Bounce back! Teacher's handbook. French's Forest Australia: Pearson Education.

Miles, S., \& Stipek, D. (2006). Contemporaneous and longitudinal associations between social behavior and literacy achievement in a sample of low-income elementary school children. Child Development, 77(1), 103-117.

Moir, D. (2016). Students' Broken Moral Compasses. Retrieved on January 2019 from https://www.theatlantic.com/education.

Noddings, N. (1988). An ethic of caring and its implications for instructional arrangements. American Journal of Education, 96(2), 2 15-230.

Nucci, L. (2006). Education for Moral Development. In M.Killen \& J.Smetana (Eds), Handbook of Moral Development. New Jersey: Lawrence Erlbaum Associate.

Nucci, L.P., \& Narvaez, D. (Eds.) (2008). Handbook of moral and character education. London: Routledge.

Patterson, E. W. (2001). Structuring the composition process in scientific writing. International Journal of Science Education, 23(4), 1-16. https://doi.org/10.1080/0950069940160401

Personal and Social Development, Well-Being and Cultural Diversity. (2008). 46. Cardiff: Department for Children, Education, Lifelong Learning and Skills.

Piaget, J. (1965). The moral judgment of the child. New York: Harcourt, Brace

Pike, M. A. (2010). Christianity and character education: Faith in core values? Journal of Beliefs \& Values: Studies in Religion \& Education, 31(3), 311-312.

Reddy, R., Rhodes, J. E., \& Mulhall, P. (2003). The influence of teacher support on student adjustment in the middle school years: A latent growth curve study. Development and Psychopathology , 15(1), 119-138. doi: 10.1017/S0954579403000075 
Roy, S. (2013). Importance of Moral Values in Student Life. Retrieved November 30, 2019, from http://www.importantindia.com/6898/importance-of-moral-values-instudent-life.

Roseth, C. J. (2016). Character education, moral education, and moral-character education. In L. Corno \& E. M. Anderman (Eds.), Handbook of educational psychology (p. 213-225). Routledge/Taylor \& Francis Group.

Törnroos, J. (2005). Mathematics textbooks, opportunity to learn and student achievement. Studies in Educational Evaluation, 31(4), 315-327.

Walberg, H. J. (1984). Improving the productivity of America's schools. Journal of Educational Leadership, 41(8), 19-27.

Walliman, N. (2010). Research Methods: The Basics. New York, NY: Routledge.

Watson, M. (2008). Developmental Discipline and Moral Education. In L.P., Nucci, \& D.,Narvaez. (Eds.), Handbook of Moral and Character Education. London : Routledge.

Whitehouse.gov. (2009). Remarks by the President in a national address to America's school children. Retrieved on May 20, 2013 from http://whitehouse.gov/the press office/Remarks-bv the-President-in-a-National

Address-to-AmericasSchoolchildren

Yore, L., Craig, M., \& Maguire, T. (1998). Index of science reading awareness: An interactive-constructive model, test verification, and grades 4-8 results. Journal of Research in Science Teaching, 35, 27-51.

Zdenek, B., \& Schochor, D. (2007). Developing moral literacy in the classroom. Journal of Educational Administration, 45(4), 514-531.

\section{Appendix A \\ QUESTIONNAIRE FOR TEACHERS AND ADMINISTARTORS}

Please write your answer in the space provided.

1. Respondent's Name (optional) 2. Gender

3. Qualification

4. Designation:

5. Years of teaching experience:

Instruction: Please encircle the option that indicates your opinion about each of the statement below

Key: $S A=$ Strongly Agree, $A=$ Agree, $N=$ Neutral, $D=$ Disagree, $S D=$ Strongly Disagree

\begin{tabular}{|c|c|c|c|c|c|c|}
\hline No & Statement & 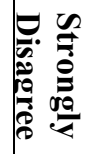 & 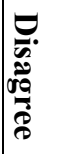 & בֶ. & $\frac{d}{80}$ & 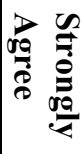 \\
\hline $\mathbf{A}$ & $\begin{array}{l}\text { Development of Empathy } \\
\text { The materials in readers used for teaching English stimulate grade } 1 \\
\text { learners to: }\end{array}$ & & & & & \\
\hline 1. & accept empathetic behaviour while reading text & SD & $\mathrm{D}$ & $\mathrm{N}$ & A & SA \\
\hline 2. & discuss empathy in class while dealing with other class mates & SD & $\mathrm{D}$ & $\mathrm{N}$ & A & SA \\
\hline 3. & differentiate empathetic behaviour while talking about matters & SD & $\mathrm{D}$ & $\mathrm{N}$ & A & SA \\
\hline 4. & adapt empathetic behaviour while dealing with issues/ problems & SD & $\mathrm{D}$ & $\mathrm{N}$ & A & SA \\
\hline 5. & perform empathetic behaviour by helping others & SD & $\mathrm{D}$ & $\mathrm{N}$ & A & SA \\
\hline
\end{tabular}




\begin{tabular}{|c|c|c|c|c|c|c|}
\hline B & $\begin{array}{l}\text { Development of Respect } \\
\text { The materials in readers used for teaching English stimulate grade } 1 \\
\text { learners to: }\end{array}$ & & & & & \\
\hline 1. & observe respectful behaviour during the class discussion & $\mathrm{SD}$ & $\mathrm{D}$ & $\mathrm{N}$ & A & SA \\
\hline 2. & behave respectfully while talking to junior staff members & $\mathrm{SD}$ & $\mathrm{D}$ & $\mathrm{N}$ & A & SA \\
\hline 3. & prefer respect on all other matters & SD & $\mathrm{D}$ & $\mathrm{N}$ & $\mathrm{A}$ & $\mathrm{SA}$ \\
\hline 4. & organize respectful behaviour while arguing with others & $\mathrm{SD}$ & $\mathrm{D}$ & $\mathrm{N}$ & $\mathrm{A}$ & $\mathrm{SA}$ \\
\hline 5. & perform respectful behaviour in different conflicts & $\mathrm{SD}$ & $\mathrm{D}$ & $\mathrm{N}$ & A & $\mathrm{SA}$ \\
\hline $\mathbf{C}$ & $\begin{array}{l}\text { Development of Caring attitude } \\
\text { The materials in readers used for teaching English stimulate grade } 1 \\
\text { learners to: }\end{array}$ & & & & & \\
\hline 1. & realise the effects of caring attitudes & $\mathrm{SD}$ & $\mathrm{D}$ & $\mathrm{N}$ & $\mathrm{A}$ & $\mathrm{SA}$ \\
\hline 2. & present the caring attitude during class activities & $\mathrm{SD}$ & $\mathrm{D}$ & $\mathrm{N}$ & $\mathrm{A}$ & $\mathrm{SA}$ \\
\hline 3. & value the caring attitude while playing in ground & $\mathrm{SD}$ & $\mathrm{D}$ & $\mathrm{N}$ & $\mathrm{A}$ & $\mathrm{SA}$ \\
\hline 4. & analyse the outcomes of caring attitude & $\mathrm{SD}$ & $\mathrm{D}$ & $\mathrm{N}$ & $\mathrm{A}$ & $\mathrm{SA}$ \\
\hline 5. & construct good relations through caring attitude & $\mathrm{SD}$ & $\mathrm{D}$ & $\mathrm{N}$ & A & $\mathrm{SA}$ \\
\hline D & $\begin{array}{l}\text { Development of Honesty } \\
\text { The materials in readers used for teaching English stimulate grade } 1 \\
\text { learners to: }\end{array}$ & & & & & \\
\hline 1. & $\begin{array}{l}\text { quote different events related to honesty during the discussion of moral } \\
\text { lesson }\end{array}$ & $\mathrm{SD}$ & $\mathrm{D}$ & $\mathrm{N}$ & A & SA \\
\hline 2. & locate the factor of honesty while describing any character & $\mathrm{SD}$ & $\mathrm{D}$ & $\mathrm{N}$ & A & $\mathrm{SA}$ \\
\hline 3. & solve matters with honesty while dealing with other class mates & $\mathrm{SD}$ & $\mathrm{D}$ & $\mathrm{N}$ & A & $\mathrm{SA}$ \\
\hline 4. & outline the boundaries of honesty while playing a game & $\mathrm{SD}$ & $\mathrm{D}$ & $\mathrm{N}$ & A & $\mathrm{SA}$ \\
\hline 5. & represent honesty as a best policy while writing narrative & SD & $\mathrm{D}$ & $\mathrm{N}$ & A & $\mathrm{SA}$ \\
\hline $\mathrm{E}$ & $\begin{array}{l}\text { Development of Perseverance } \\
\text { The materials in readers used for teaching English stimulate grade } 1 \\
\text { learners to: }\end{array}$ & & & & & \\
\hline 1. & receive perseverance while reading text & $\mathrm{SD}$ & $\mathrm{D}$ & $\mathrm{N}$ & A & $\mathrm{SA}$ \\
\hline 2. & show perseverance while defending their view point during discussions & $\mathrm{SD}$ & $\mathrm{D}$ & $\mathrm{N}$ & A & $\mathrm{SA}$ \\
\hline 3. & balance their perseverance while showing flexibility to classmates & SD & $\mathrm{D}$ & $\mathrm{N}$ & A & $\mathrm{SA}$ \\
\hline 4. & $\begin{array}{l}\text { improve their perseverance while facing different academic and social } \\
\text { problems }\end{array}$ & $\mathrm{SD}$ & $\mathrm{D}$ & $\mathrm{N}$ & A & $\mathrm{SA}$ \\
\hline 5. & authenticate perseverance while presenting themselves in front of seniors & $\mathrm{SD}$ & $\mathrm{D}$ & $\mathrm{N}$ & A & $\mathrm{SA}$ \\
\hline
\end{tabular}

Thank you very much for your time. 